\title{
PENERAPAN MODEL PEMBELAJARAN COOPERATIVE SCRIPT UNTUK MENINGKATKAN KEMAMPUAN BERPIKIR KREATIF MATEMATIS SEKOLAH MENENGAH PERTAMA (SMP)
}

\author{
Nita Yudiawati ${ }^{1}$ dan Beni Yusepa, G.P. ${ }^{2}$ \\ Pendidikan Matematika FKIP Universitas Pasundan \\ 1)email: nita.yudiawati15@gmail.com \\ ${ }^{2)}$ email: pyusepa.fkip.pmat@unpas.ac.id
}

\begin{abstract}
ABSTRAK
Penelitian ini bertujuan untuk menelaah kemampuan berpikir kreatif matematis siswa antara siswa yang memperoleh pembelajaran model Cooperative Script dengan siswa yang memperoleh pembelajaran konvensional. Metode yang digunakan adalah metode eksperimen dengan desain kelompok kontrol pretespostes. Populasi dalam penelitian ini seluruh siswa kelas VIII SMP Nasional Bandung. Adapun sampel penelitiannya adalah dua kelas yang dipilih secara acak kelas yaitu VIII-A sebagai kelas kontrolyang di berikan perlakuan pembelajaran konvensional dan VIII-B sebagai kelas eksperimen diberikan perlakuan pembelajaran model Cooperative Script. Tes yang digunakan adalah tes uraian. Sedangkan skala sikap menggunakan Skala Likert yang berisikan pernyataanpernyataan siswa mengenai kepercayaan diri siswa terhadap kegiatan pebelajaran yang dilakukan. Temuan penelitian ini menunjukkan: 1) Peningkatan kemampuan berpikir kreatif matematis siswa yang memperoleh model pembelajaran Cooperative Script lebih baik daripada siswa yang memperoleh pembelajaran konvensional; 2) Kepercayaaan diri siswa terhadap pembelajaran matematika yang menggunakan model pembelajarn Cooperative Script lebih baik daripada siswa yang menggunakan model pembelajaran konvensional. Siswa bersikap positif terhadap pelajaran matematika, pembelajaran model Cooperative Script, dan soalsoal kemampuan berpikir kreatif matematis.
\end{abstract}

Kata kunci: cooperative script, berpikir kreatif, kemampuan berpikir kreatif matematis. 


\section{PENDAHULUAN}

Belajar adalah suatu proses yang menyebabkan terjadinya suatu pembaharuan dalam tingkah laku, berhasil atau tidaknya belajar itu tergantung kepada beberapa faktor yang dibedakan menjadi dua faktor. Faktor tersebut antara lain, faktor internal dan eksternal. Faktor internal meliputi intelegensi, motivasi, kebiasaan, kecemasan, minat, dan sebagainya. Sedangkan faktor eksternal meliputi lingkungan kelurga, lingkungan sekolah, lingkungan masyarakat, keadaan sekolah, keadaan ekonomi, dan sebagainya Ahmad (Nurhadijah; 2004, hlm.138).

Matematika adalah ratunya ilmu (Mathematics it the Queen of the Sciences), maksudnya antara lain ialah bahwa matematika tidak bergantung kepada bidang studi lain; bahasa, dan agar dapat difahami orang dengan tepat kita harus menggunakan simbol dan istilah yang cermat yang disepakati secara umum (Ruseffendi, 2006, hlm. 260261). Matematika merupakan kunci utama dari pengetahuan-pengetahuan lain yang dipelajari disekolah. Menurut Ruseffendi (2006, hln. 260), matematika timbul karena fikiran-fikiran manusia, yang berhubungan dengan ide, proses, dan penalaran. Siswa mempelajari matematika hendaknya mampu mengaitkan pengetahuan yang telah dimiliki dengan pengetahuan yang sedang siswa pelajari.

Salah satu visi pembelajaran matematika, tujuan pendidikan nasional, dan tujuan pembelajaran matematika sekolah di antaranya adalah kemampuan berpikir kreatif. Visi yang dimaksud diantaranya adalah mengembangkan kemampuan matematik: penguasaan konsep matematika dan penerapannya, serta memberi peluang berkembangnya kemampuan menalar yang logis, sistematis, kritis dan cermat, serta kreatif yang sangat diperlukan dalam menghadapi masa depan yang selalu berubah (Rohaeti \& Budiyanto, 2014, hlm. 166).

Perubahan paradigma dalam pembelajaran matematka telah telah membawa banyak perubahan kemampuan seorang siswa dalam bermatematika. Selain perubahan paradigma pembelajaran matematika, kemajuan SDM pun menuntut yang handal dalam bidangnya, yang tidak sekedar pandai namun juga kreatif (Kurniasi, 2012, hlm. 62). Menurut Purnomowati (Kurniasi; 2012, hlm, 62) , "salah satu indikator peningkatkan kualitas sumber daya manusia adalah terbentuknya manusiamanusia kreatif". Dalam matematika kemampuan berpikir kreatif sangkatlah diperlukan karena kemampuan berpikir kreatif mendorong sesorang terampil memecahkan masalah dalam matematika dan menemukan alternatif-alternatif pemecahan yang bervariasi. Kemampuan berpikir kreatif adalah kemmapuan menganalisis sesuatu berdasarkan data atau informasi yang tersedia dan menemukan alternatif-alternatif jawaban terhadap suatu masalah yang penekananya pada kuantitas, ketepatgunaan, dan keraragaman jawaban (Budiarto, F \& Eliyarti, W, 2013, hlm. 298).

Namun kenyataannya, kemampu-an berpikir kreatif matematis siswa masih rendah. Hasil penelitian Hans Jellendari dan Klaus Urban (Kurniasi dalam Mina, 2012, hlm. 62) dari Universitas Utah Amerika Serikatdan Universitas Hanover mengungkapkan bahwa kreatifiitas anak-anak Indonesia dibandingkan dengan negara-negara lain berada diperingkat rendah. Penelitian ini dilakukan dengan mengambil sampel 50 anak berusia 10 tahun di Jakarta. Selain ini, hasil study yang dilakukan TIMSS, ketika memberikan contoh soal kempuan berpikir kreatif matematis hanya $25,2 \%$ saja siswa di Indoensia yang bisa menjawab dengan benar, sisanya menjawab salah. Edistira (Kurniasi, 2012, hlm. 62).

Demikian juga hasil observasi langsung diperoleh data bahwa hasil-hasil ujian matematika baik Ujian Tengah Semester maupun Ujian Akhir Semester belum memuaskan. Sikap dan keterampilan berpikir kreatif matematis siswa cenderung masih rendah. Siswa masih terbiasa mengerjakan soal yang telah dicontohkan oleh guru. Diduga salah satu penyebanya adalah karena pembelajaran matematika masih menganut jenis pembelajaran 
tradisional (Turmudi, 2010). Oleh karena itu, perlu adanya upaya untuk memperbaiki pembelajaran matematika di kelas. Memenuhi tuntutan perkembangan zaman yang semakin maju, aspek pendidikan diharuskan membimbing dan mengarahkan peserta didik untuk menjadi lebihaktif dan kreatif. Menurut Yusepa (2016c dan 2016d), Guru memiliki peranan penting dalam proses pembelajaran dan dalam meningkatkan pendidikan nasional serta menjadi garda terdepan pendidikan. Lebih lanjut Yusepa (2016c) mengatakan bahwa agar pembelajaran menjadi bermakna maka guru harus mampu membelajarkan siswa dengan model atau pendekatan pembelajaran yang bervariasi

Keberhasilan siswa dalam pembelajaran tergantung bagaimana cara siswa mengatasi kesulitan yang ada. Untuk menumbuhkan kemampuan berpikir kreatif matematis, yaitu memunculkan gagasan atau ide matematis yang baru dibutuhkan sikap yang tidak mudah menyerah dalam menghadapi tantangan. Sehingga dalam kemampuan berpikir kreatif matematis juga dibutuhkan kemampuan kepercaya-an diri.

Rendahnya hasil belajar siswa dalam bidang matematika, salah satunya disebabkan oleh masih rendahnya pemahaman konsepkonsep matematika dan kreatifitas siswa dalam menye-lesaikan soal-soal. Untuk membangun pemahaman konsep siswa maka perlu memerlukan sebuah model pembelajaran dimana siswa bisa mencapai hasil akademik dan sosial termasuk bisa meningkatkan prestasi, percaya diri, dan hubungan interpersonal positif antara siswa satu dengan sisiwa lainnya.

Slavin (1994, hlm. 175) mengata-kan bahwa salah satu model pembelajaran yang dapat meningkatkan daya ingat siswa adalah model pembelajaran Coopetaive Script. Dengan meningkatkan daya ingat siswa pada materi yang telah diperoleh sebelumnya., dapat pula mempermudah meningkatkan kreatifitas siwa karena kreatifitas siswa merupakan kemampuan membuat kombinasi baru berdasarkan data dan informasi yang sudah ada. Cooperative Script adalah model pembelajaran dimana siswa bekerja berpasangan dan mengikhtisarkan bagianbagian dari materi yang dipelajari.

Model pembelajaran Cooperative Script merupakan salah satu bentuk model pembelajaran kooperatif. Dalam perkembangan pembelajarannya, model pembelajaran Cooperative Script telah mengalami banyak adaptasi, sehingga melahirkan beberapa pengertian dan bentuk yang sedikit berbeda antara yang satu dengan yang lainnya, namun pada intinya sama. Pada model pembelajaran Cooperative Script siswa akan dipasangkan dengan temannya dan akan berperan sebagai pembicara dan pendengar. Pembicara membuat kesimpulan dari materi yang akan disampaikan kepada pendengar, dan pendengar akan menyimak, mengoreksi, menunjukkan ide-ide pokok yang kurang lengkap. Menurut Armansyah (2014, hlm. 67), "model pembelajaran Cooperative Script adalah model pembelajaran yang dapat meningkatkan hubungan sosial antara siswa dengan siswa untuk menyelesaikan tujuan bersama-sama". Sedangkan menurut Yuniarsih (2015, hlm. 4), "model pembelajaran Cooperative Script adalah suatu kesepakatan antara siswa dengan guru dan siswa dengan siswa untuk berkolaborasi memecahkan suatu masalah dalam pembelajaran dengan cara-cara yang kolaboratif seperti halnya menyelesaikan masalah yang terjadi dalam kehidupan sosial siswa".

Manfaat model pembelajaran Cooperative Script adalah untuk memudahkan siswa dalam mengerjakan tugasnya dan membantu siswa mengingat kembali materi yang telah dipelajari serta memberikan siswa membenarkan kesalahpahaman yang dialami siswa, dapat meningkatkan keepektifan pelaksanaan pembelajaran, dapat memperluas cakupan perolehan materi pembelajaran, dapat melatih keterampilan berpikir kritis dan kreatif peserta didik dalam menganalisis, merangkum, dan melalui kegiatan diskusi siswa akan terlatih menggunakan kemampuan berpikir kreatifnya untuk memperoleh pengetahuan melalui 
pembelajaran yang dirancang pada model pembelajaran Cooperative Script.

Langkah-langkah untuk menerapkan model pembelajran Coopertive Script menurut Riyanto (2009, hlm. 280), adalah sebagai berikut:

1) Guru membagi siswa untuk berpasangan.

2) Guru membagiakan wacana/materi tiap siswa untuk dibaca dan membuat ringkasan.

3) Guru dan siswa menetapkan siapa yang pertama berperan sebagai pembicara dan siapa yang berperan sebagai pendengar.

4) Pembicara membacakan ringkasannya selengkap mungkin dengan memasuk-kan ide-ide pokok dalam ringkasannya, sementara pendengar:

5) Menyimak/mengoreksi/melengkapi ide-ide pokok yang kurang lengkap.

6) Membantu mengingat/menghafal ide/ide pokok dengan menghubungkan materi sebelumnya atau dengan materi lainnya.

7) Bertukar peran, semula berperan sebagai pembicara ditukar menjadi pendengar dan sebaliknya. Kemudian lakukan seperti kegiatan tersebut kembali.

8) Merumuskan kesimpulan bersamasama siswa dan guru.

9) Penutup.

\section{Kemampuan Berpikir Kreatif Matematis}

Menurut Torrance (Munandar; 2009, hlm. 27), "kreativitas adalah merasakan dan mengganti adanya masalah, membuat dugaan tentang kekurangan (masalah) ini, menilai dan menguji dugaan atau hipotesis, kemudian menguji dan mengubah lagi, dan akhirnya menyampaikan hasil-hasilnya". Kemampuan berpikir kreatif matematis merupakan salah satu tujuan yang harus dicapai dalam pembelajaran matematika di sekolah.

Menurut Azhari (2013, hlm. 5), "kemampuan berpikir kreatif merupakan hal yang dimiliki seseorang sejak ia lahir. Berpikir kreatif ini harus terus dikembangkan dan dilatih". Guru dapat melatih kemampuan berpikir kreatif siswa dalam suasana pembelajaran di kelas. Salah satunya menerapkan pembelajaran yang bisa memberikan siswa kesempatan dalam mengemukakan dan mengembangkan gagasan mereka secara bebas namun tetap dibawah bimbingan guru sebagai fasilitator. Untuk mengetahui tingkat kekreatifan seseorang, perlu adanya penilaian terhadap kemampuan berpikir kreatif pada orang tersebut. Penilai tersebut harus meliputi empat kriteria dari berpikir kreatif, yaitu kelancaran, kelenturan, keaslian, dan keterperincian dalam mengemukakan gagasan.

Guilford (Munandar; 2009, hlm. 64), mengemukakan bahwa untuk menilai kemampuan berpikir kreatif ada 5 komponen kunci, yaitu:

a. Fluency (kelancaran), yaitu kemampuan untuk menghasilkan banyak gagasan.

b. Flexibility (keluwesan), yaitu kemampuan mengubah bermacam-macam pendekatan dalam mengatasi persoalan.

c. Elaboration (elaborasi), yaitu kemampuan menyatakan gagasan secara terperincin.

d. Sensitivity (kepekaan), yaitu kemampuan menangkap dan menghasilkan masalah-masalah sebagai tanggapan terhadap suatu situasi.

Kemampuan berpikir kreatif matematis dapat dirumuskan sebagai kemampuan mengungkapkan jawaban dan gagasan beragam yang dianggap paling tepat dan paling baik dalam menyelesaikan suatu masalah dan gagasan tersebut asli atau berasal dari pemikirannya sendiri meskipun merupakan gabungan dari beberapa gagasan yang telah ada sebelumnya. Gie (Sunaryo; 2014, hlm. 45), menyatakan "Berpikir kreatif (creative thinking) adalah suatu pemikiran yang berusaha menciptakan sesuatu gagasan yang baru". 


\section{METODE PENELITIAN}

Metode yang digunakan dalam penelitian ini adalah metode ekperimen. Menurut Ruseffendi (2010, hlm. 35), "Penelitian eksperimen adalah penelitian yang benar-benar untuk melihat sebab-akibat. Disain penelitian ini adalah desain kelompok kontrol pretes-postes (pretest-posttest control grup design) yang melibatkan dua kelompok. Karena penelitian ini tergolong pada penelitian eksperimen atau percobaan, Sehingga desain penelitiannya adalah sebagai berikut (Ruseffendi, 2010, hlm. 50):

$\begin{array}{llll}\text { A } & \text { O } & \text { X } & \text { O } \\ \text { A } & \text { O } & & \text { O }\end{array}$

Keterangan :

A: Sampel Acak Kelas

B: Pretes $=$ Postes

C: Pemberian perlakuan model pembelajaran Cooperative Script dalam kegiatan belajar mengajar.

Adapun yang menjadi Populasi dalam penelitian ini adalah adalah siswa kelas VIII SMP Nasional Bandung tahun ajaran 2016/2017. Teknik pengambilan sampel adalah acak menurut kelas, dengan memilih 2 kelas, yaitu kelas eksperimen dan kelas kontrol. Instrumen tes yang digunakan adalah tipe soal uraian. Hal ini dikarenakan soal uraian dapat memperlihatkan sifat kreatif siswa dalam menyelesaikan soal-soal bervariasi.

Uji peningkatan kemampun berpikir kreatif matematis siswa bertujuan untuk melihat perbedaan peningkatan kemampuan berpikir kreatif matematis siswa antara yang menggunakan model pembelajaran Cooperative Script dan yang menggunakan model pembelajaran konvensional. Setelah data hasil pretes dan postes dianalisis, besarnya mutu peningkatkan kemampuan berpikir kreatif matematis siswa dihitung dengan menggunkan rumus gain ternormalisasi.

\section{HASIL DAN PEMBAHASAN}

Berikut ini adalah sajian statistik deskriptif skor pretes dan Gain untuk kemampuan berpikir kreatif matematis

Tabel 1.

Statistik Deskripsi Data Hasil Pretes

\begin{tabular}{ccccccc}
\hline \multirow{2}{*}{ Kelas } & \multicolumn{6}{c}{ Tes Awal (Pretes) } \\
\cline { 2 - 7 } & $\mathrm{N}$ & $\begin{array}{c}\text { Skor } \\
\text { Maksimum }\end{array}$ & $\begin{array}{c}\text { Skor } \\
\text { Minimum }\end{array}$ & $\begin{array}{c}\text { Skor } \\
\text { Rerata }\end{array}$ & $\begin{array}{c}\text { Simpangan } \\
\text { Baku }\end{array}$ & Varians \\
\hline Eksperimen & 31 & 35 & 5 & 17,18 & 7,89 & 62,39 \\
\hline Kontrol & 31 & 30 & 0 & 13,23 & 6,89 & 47,58 \\
\hline
\end{tabular}

Berdasarkan kategorisasi data yang terlihat pada Tabel 1, rata-rata kemampuan awal berpikir kreatif matemtis siswa kelas eksperimen adalah 17,18 dan rata-rata kemampuan awal berpikir kreatif matematis siswa kelas kontrol adalah 13,23. Hal ini menunjukan kemampuan awal siswa kelas eksperimen lebih tinggi daripada siswa kelas kontrol.

Analisis skor pretes menggunakan uji perbedaan rataan pretes. Uji perbedaan rataan pretes bertujuan untuk memperlihatkan ada berikut.

Tabel 2.

Uji Normalitas Skor Pretes Kemampuan Berpikir Kreatif Matematis

\begin{tabular}{llrrr}
\hline \multirow{2}{*}{ Kelas } & \multicolumn{3}{c}{ Shapiro-Wilk } \\
\cline { 2 - 5 } NilaiPretes & Eksperimen & Statistic & df & \multicolumn{1}{c}{ Sig. } \\
\cline { 2 - 5 } & Kontrol &, 939 & 31 &, 070 \\
& & & 31 &, 076 \\
\hline
\end{tabular}


Berdasarkan Tabel 2, terlihat bahwa datapretes siswa kelas eksperimen memiliki signifikan 0,070 dan kelas kontrol memiliki nilai signifikan 0,76 . Nilai signifikan kedua kelas lebih besar dari 0,05. Maka, dapat disimpulkan bahwa data tes awal kedua kelas berdistribusi normal.

Selanjutnya, karena data sampel berdistribusi normal maka dilakukan uji homogenitas varians.Untuk menguji homogenitas varians data pretes kelas eksperimen dan kelas kontrol pada penelitian ini, digunakan statistik uji Levene's test foe equality dengan taraf signifikan 0,05 menggunakan software SPSS 18.0 for windows.

Tabel 3.

Uji Homogenitas Dua Varians Skor Pretes Kemampuan Berpikir Kreatif Matematis

\begin{tabular}{crrr}
\hline $\begin{array}{l}\text { Levene } \\
\text { Statistic }\end{array}$ & df1 & df2 & Sig. \\
\hline 2,134 & 1 & 60 &, 149 \\
\hline
\end{tabular}

Berdasarkan Tabel 3, terlihat bahwa bahwa data pretes kedua kelas memiliki nilai signifikan yang lebih besar dari 0,05 yaitu sebesar 0,149. Sehingga, dapat disimpulkan bahwa kedua data tersebut mempunyai varians sama atau kedua kelas tersebut homogen.

Kedua kelas tersebut berdistribusi normal dan memiliki varians yang homogen, selanjutnya dilakukan uji kesamaan dua rerata dengan uji-t melalui program SPSS 18.0 for windows dengan menggunakan Independent Sample t-Test dengan asumsi kedua varians homogen (equal varins assumed) dengan taraf signifikannya 0,05 . Hipotesis yang digunakan dalam pengujian ini yaitu hipotesis komparatif dua sampel dengan uji dua pihak sebagai berikut (Sugiyono, 2012, hlm. 120).

Tabel 4.

Uji Kesamaan Dua Rerata

\begin{tabular}{|c|c|c|c|c|c|}
\hline & & $\mathrm{T}$ & Df & $\begin{array}{l}\text { Sig. (2- } \\
\text { tailed) }\end{array}$ & Mean Difference \\
\hline NilaiPretes & $\begin{array}{l}\text { Equal variances } \\
\text { assumed }\end{array}$ & 2,098 & 60 & ,040 & 3,952 \\
\hline
\end{tabular}

Dari Tabel 4 terlihat bahwa nilai signifikan dengan asumsi kedua varians homogen (equal varians assumed) adalah 0,040. Nilai tersebut lebih kecil dari 0,05. Sehingga $H_{o}$ ditolak dan $H_{1}$ diterima. Jadi, dapat disimpulkan bawha terdapat perbedaan yang signifikan antara kemampuan awal berpikir kreatif matematis siswa kelas eksperimen dan kelas kontrol. Hal ini terlihat dari hasil nilai rata-rata kelas eskperimen lebih besar daripada nilai rata-rata kelas kontrol.
Dengan demikian analisis data dilanjutkan dengan analisis data gain.

Karena hasil pretes menunjukkan bahwa kemampuan berpikir kreatif matematis siswa kelas eksperimen dan kelas kontrol pada tes awal berbeda secara signifikan, maka selanjutnya akan dilakukan analisis data gain untuk mengetahui keberartian dan peningkatan kemampuan berpikir kreatif matematis siswa dari pretes ke postes antara kelas eksperimen dan kelas kontrol.

Tabel 5.

Statistika Deskriptif Data Gain

\begin{tabular}{ccccccc}
\hline Kelas & N & $\begin{array}{c}\text { Nilai } \\
\text { Maksimum }\end{array}$ & $\begin{array}{c}\text { Nilai } \\
\text { Minimum }\end{array}$ & Rata-rata & $\begin{array}{c}\text { Simpangan } \\
\text { Baku }\end{array}$ & Varinas \\
\hline Eksperimen & 31 & 75 & -5 & 33,84 & 20,66 & 426,71 \\
\hline Kontrol & 31 & 70 & -15 & 25,32 & 17,70 & 313,23 \\
\hline
\end{tabular}


Deskripsi di atas menunjukkan bahwa rata-rata gain siswa kelas eksperimen adalah 33,84 . Sedangkan rata-rata gain siswa kelas kontrol adalah 25,32. Kemudian diperoleh simpangan baku untuk kelas eksperimen dan kelas kontrol sebesar 20,66 dan 17,70. Hasil analisis dekriptif ini memberikan gambaran bahwa rata-rata gain siswa kelas eksperimen berbeda dengan rata-rata gain siswa kelas kontrol.

Karena kedua kelompok data berasal dari populasi yang berdistribusi normal dan mempunyai varinas yang homogen, maka untuk mengetahui apakah perbedaan rata-rata gain cukup berarti atau tidak dihitung dengan menggunakan uji t-tes dengan bantuan software SPSS 18.0 for windows.

Tabel 6.

Output Uji Kesamaan Dua Rerata Data Gain Kelas Eksperimen dan Kelas Kontrol

\begin{tabular}{lccccc}
\hline & \multicolumn{3}{c}{ t-test for Equality of Means } \\
\cline { 3 - 5 } & Equal variances assumed & & T & df & Sig. (2-tailed) \\
\hline Gain & & & 60 & 0,086 \\
& & & &
\end{tabular}

Berdasarkan Tabel 3, terlihat bahwa nlai signifikan uji dua pihak (sig.2-tailed) dengan asumsi kedua varians homogen (equal varians assumed) adalah 0,086. Menurut Uyanto (2006, hlm. 120), "untuk melakukan uji satu pihak nilai sig (2-tailed) harus dibagi dua". Sehingga, $\frac{0,086}{2}=0,043<0,05$. Sehingga berdasarkan kriteria pengujian $H_{o}$ ditolak dan $H_{1}$ diterima. Peningkatan berpikir krestif matematis siswa yang mendapatkan model pembelajaran Cooperative Script lebih besar daripada peningkatan berpikir kreatif matematis siswa yang mendapatkan model pembelajaran konvensional. Hal ini terlihat dari hasil nilai rata-rata skor gain kelas eksperimen lebih tinggi daripada rata-rata skor gain kelas kontrol.

Berdasarkan hasil penelitian, diperoleh adanya peningkatan yang signifikan kemampuan berpikir kreatif matematis siswa yang mendapatkan model pembelajaran Cooperative Script dengan siswa yang mendapatkan model pembelajaran konvensional. Pada tes awal (Pretes), terdapat perbedaan diantara keduanya artinya kedua kelas memiliki kemampuan yang berbeda pada awal sebelum diberikan perlakuan. Seiring dengan berjalannya proses pembelajaran, kedua kelas mengalami perubahan. Seperti yang telah diungkapkan sebelumnya bahwa tanda dari belajar adalah perubahan. Surya (Faridah; 1981, hlm. 32) menegaskan bahwa suatu proses usaha yang dilakukan individu untuk memperoleh suatu perubahan tingkah laku yang baru keseluruhannya, sebagai hasil pengalaman individu itu sendiri dalam interaksinya dengan lingkungannya.

Perubahan hasil belajar siswa ditunjukkan dengan adanya peningkatan kemampuan berpikir kreatif matematis dari kedua kelas. Tampak terlihat dari hasil penelitian, peningkatan kemampuan berpikir kreatif matematis siswa yang mendapatkan model pembelajaran Cooperative Script lebih baik daripada siswa yang mendapatkan model pembelajaran konvensional. Hal ini sesuai dengan yang dikemukakn oleh Ruseffendi (2006, hlm. 22) strategi atau teknik mengajat diperlukan oleh setiap guru agar yang diperoleh siswa itu semaksimal mungkin.

Pembelajaran berjalan dengan baik walaupun pada pertemuan pertama siswa tampak kaku dengan kegiatan pembelajaran yang berlangsung. Hal tersebut dapat disebabkan oleh beberapa faktor, yaitu (1) Siswa belum terbiasa dengan pembelajaran yang diberikan, (2) Siswa memerlukan adaptasi terhadap pembelajaran yang diberikan. Pada pertemuan berikutnya pembelajaran berjalan dengan baik. Siswa sudah beradaptasi dan memahami pembelajaran yang sedang berlangsung. 
Selama pembelajaran matematika dengan model Cooperative Scipt, peneliti mendapati beberapa kendala walaupun peneliti telah melakukan banyak hal untuk meminimalisir kendala-kendala tersebut. Kendala pada kelas eksperimen adalah pelajaran terakhir, dan setelah dilakukannya pelajaran olahraga. Terkadang kondisi siswa sudah tidak kondusif lagi untuk belajar di kelas karena siswa terlihat cape, apalagi belajar mata pelajaran matematika. Namun, guru tetap memberikan semangat dan membantu siswa mempelajari materi semaksimal mungkin, serta memberikan arahan dan penjelasana tentang pentingnya materi dalam pembelajaran tersebut. selain itu, waktu yang dibutukan dalam penggunaam model pebelajaran Cooperative Script terutama kemampuan peserta didik dalam menyelesaikan masalah sangat panjang. Oleh karena itu, penggunaan waktu yang efektif harus benar-benar diatur sedemikian sehingga tujuan pembelajaran setiap pertemuan dapat dicapai.

\section{KESIMPULAN}

Berdasarkan uraian hasil dan pembahasan yang telah dikemukakan, kesimpulan yang diperoleh adalah bahwa peningkatan kemampuan berpikir kreatif matematis siswa yang menggunakan model pembelajaran Cooperative Script lebih baik daripada siswa yang menggunakan model pembelajaran konvensional.

\section{REKOMENDASI}

Model pembelajaran Cooperative Script dapat dijadikan sebagai alternatif untuk pembelajaran matematika dalam upaya meningkatkan kemampuan berpikir kreatif matematis siswa.

\section{DAFTAR RUJUKAN}

Armansyah. (2014). Pengaruh penerapan model pembelajaran cooperative script terhadap hasil belajar siswa pada mata pelajaran biologi kelas viii4 smp negeri 1 makassar. Jurnal
Nalar Pendidikan, 2 (1). 6671.https://www.google.com/url?sa=t\& $\mathrm{rct}=\mathrm{j} \& \mathrm{q}=\& \mathrm{esrc}=\mathrm{s} \&$ source $=$ web $\& \mathrm{~cd}=$ $8 \& \mathrm{cad}=\mathrm{rja} \&$ uact $=8 \& \mathrm{ved}=0 \mathrm{ahUKEwj}$ o1YGgtZrUAhUHP48KHR9-

BRMQFghYMAc\&url=http $\% 3 \mathrm{~A} \% 2 \mathrm{~F}$ $\% 2$ Fojs.unm.ac.id\%2Findex.php $\% 2 \mathrm{~F}$ nalar\%2Farticle\%2Fdownload\%2F19 62\%2F946\&usg=AFQjCNF9AensFY byMswsyd6WvCBXPBSYHQ\&sig2= mSPHpVJ7V8uRT6e-FupiRQ.

(Diakes tanggal 31 Mei 2017).

Azhari. (2013). Peningkatan kemampuan berpikir kreatif matematik siswa melalui pendekatan konstruktivisme di kelas VII sekolah menengah pertama (smp) negeri 2 banyuasin. Jurnal pendidikan matematika, 7 (2). 1-11. http://ejournal.unsri.ac.id/index.php/jp m/article/viewFile/992/364.

(Diakes tanggal 31 Mei 2017).

Budiarto, F \& Eliyarti, W. (2013). Pengaruh Penggunaan Pendekatan Opend-Ened Terhadap Peningkatan Kemampuan Berpikir Kreatif Matematik Pada Siswa SMP. Jurnal Pendidikan Matematika "Symmetry", Vol.2 No. 2: 294-303.

Faridah. (2012, November). Definisi Belajar Menurut Para Ahli. (online). Tersedia:

http://widhiieaprilia.blogspot.co.id/p/b log-page_16.html?m=1.

Kurniasih. (2012). Pengaruh Pem-belajaran Matematika dengan Mind Map terhadap Kemampuan Berpikir kreatif Pada Siswa SMA. Jurnal Pendidikan Matematika "Symmetry". Vol. 1 No.1: 61-71.

Munandar. (2013). Kretaivitas dan Keterbakatan: Strategi Mewujud-kan Potensi Kreatif dan Bakat. Jakarta: PT Gramedia Pustaka.

Riyanto. (2009). Paradigma Baru Pembalajaran. Jakarta: Kencana prenada media grup. 
Ruseffendi. (2010). Dasar-Dasar Penelitian Pendidikan dan Bidang Non-Eksakta Lainnya. Bandung: Tarsito.

Ruseffendi. (2006). Pengantar Kepada Membantu Guru Mengembangkan kompetensinya dalam Pengajaran Matematika untuk Meningkatkan CBSA. Bandung: Tarsito.

Rohaeti \& Budiyanto. (2014).

Mengembangkan Kemampuan Berpikir Kreatif dan Kemandirian Belajar Siswa SMA Melalui Pembelajaran Berbasis Masalah. Jurnal Pengajaran MIPA. Vol.19 No. 2: 166-172.

Sudjana. (2005). Metode Statistika. Bandung: Tarsito Bandung.

Slavin (1994). Education Psychology: Theryand Practice, Third.

Sugiyono. (2016). Statistika untuk Penelitian. Bandung: Alfabeta.

Sunaryo. (2014). Model Pembelajaran Berbasis Masalah Untuk Meningkatkan Kemampuan Berpikir Kritis Dan Kreatif Matematik Siswa SMA Di Kota Tasikmalaya. Jurnal Pendidikan dan Keguruan. Vol. 1 No.: 41-51. (online). Tersedia: .https://www. google. co.id/url?sa $=\mathrm{t} \& \mathrm{rct}=\mathrm{j} \& \mathrm{q}=\&$ esrc $=\mathrm{s} \&$ source $=$ web $\&$ cd $=2 \&$ cad $=$ rja $\&$ uact $=8 \&$ ved $=$ 0ahUKEwiOpaLNqZnUAhXGv48KH a0_DFgQFgg1MAE\&url=http\%3A\% 2F\%2Fpasca.ut.ac.id\%2Fjournal\%2Fi ndex.php $\% 2$ FJPK\%2Farticle\%2Fdow nload\%2F58\%2F58\&usg=AFQjCNFx gIUHkMm4BtrU3wQhmAFdggSLFg \&sig2=IRe6HQj93Fmn7y0bxjgmEg.

(Diakses tanggal 31 Mei 2017).
Turmudi. (2010). Pembelajaran Matematika Kini dan Kecendrungan Masa Mendatang. (online). Tersedia: http://fle.Upi. Edu/ Direktoriat/FPMIPA/Jur_Pend_Mate matika/196101121987031Turmudi/F2_Bunga_Rampai_MIDA2 010-oke.

Undang-Undang Sisdiknas. (2003). Undangundang Republik In-donesia Nomor 20 Tahun 2003 Tentang Sistem Pendidikan Nasional. Jakarta: Depdiknas.

Uyanto, S. S. (2006). Pedoman Analisis Data dengan SPSS. Yogyakarta: Graha Ilmu.

Yuniarsih. (2015). Penerapan Model Cooperative Script Pada Pembelajaran Fisika Siswa Kelas VIII Mts Negeri Lubuklinggau Tahun Pelajaran 2014/2015. (online). Trsedia:

http://mahasiswa.mipastkipllg.com/re pository/JURNAL\%20_FAJRAH_.pd $\mathrm{f}$ page $=6 \&$ zoom $=$ auto, $-99,100$.

Yusepa, B.G.P. (2016c). Keserupaan Pembelajaran Matematika Realistik dengan Pembelajaran Matematika Konstektual. Prosiding Seminar Nasional Pendidikan Matematika. Universitas Siliwangi. Hal. 168-178. ISBN: 978-6029250-35-0

Yusepa, B.G.P. (2016d). Analisis Perbandingan Kurikulum Pendidikan Indonesia dan Inggris untuk Meningkatkan Kompetensi Pe-dagogik dan Kompetensi Pro-fesional Guru Matematika. Prosiding Seminar Nasional Matematika dan Pendidikan Matematika:Strategi Mengembangkan Kua-itas Pembelajaran Matematika Berbasis Riset. Unswagati. Hal. 346364. ISBN: 978-602-71252-1-6 
P.II'Plid Jurnal Teori dan Riset Matematika (TEOREMA) Vol. 2 No. 1, Hal, 72-72, September 2017 p-ISSN 2541-0660, e-ISSN 2597-7237 @ 2017 